\title{
Alternatives to Current Fumigation Practices in Western States Raspberry
}

Tom W. Walters, Walters Ag Consulting, Anacortes, WA 98221; Mark Bolda, UC Cooperative Extension, Watsonville, CA 95076; and Inga A. Zasada, USDA-ARS Horticultural Crops Research Laboratory, Corvallis, OR 97330

Accepted for publication 19 April 2017.

\begin{tabular}{|c|c|}
\hline \multicolumn{2}{|c|}{ Abstract } \\
\hline $\begin{array}{l}\text { Red raspberry production in the western United States is heavily } \\
\text { reliant on preplant soil fumigation to ensure the successful es- } \\
\text { tablishment and productivity of a planting. However, due to issues } \\
\text { related to the regulation, availability, and economics of soil fumi- } \\
\text { gation, alternatives are needed for current fumigation practices. } \\
\text { Trials were conducted in commercial raspberry fields in California } \\
\text { and Washington to evaluate alternatives to current fumigation } \\
\text { practices in each region. In Washington, tarped bed fumigation with } \\
1,3-\text { dichlorpropene (1,3-D):chloropicrin (Telone C-35) performed as } \\
\text { well as, and sometimes better than, the industry standard non- } \\
\text { tarped broadcast fumigation with Telone C-35 for the control of the }\end{array}$ & $\begin{array}{l}\text { soilborne pathogen Phytophthora rubi and the plant-parasitic } \\
\text { nematode Pratylenchus penetrans. In one of the Washington trials, } \\
\text { yield of raspberry grown in tarped bed-fumigated areas was } 47 \% \\
\text { greater than the yield of plants grown in nontarped broadcast- } \\
\text { fumigated areas. In California, a combination of chloropicrin:1,3-D } \\
\text { (Pic-Clor } 60 \text { ) performed as well as the industry standard of methyl } \\
\text { bromide:chloropicrin. Raspberry plants grown in soil fumigated with } \\
\text { either of these fumigants were approximately } 26 \% \text { taller than plants } \\
\text { grown in nonfumigated soil. Our results indicate that there are } \\
\text { viable fumigation alternatives to the current fumigation systems } \\
\text { used in Washington and California raspberry production systems. }\end{array}$ \\
\hline
\end{tabular}

Raspberry Production and Soilborne Pathogen

Management in the Western United States

United States red raspberry (Rubus idaeus L.) production is heavily concentrated in Santa Cruz and Ventura counties, CA, and in Whatcom Co. of Washington State. These regions share optimal moist and cool coastal climates and sandy soils needed for raspberry production. In California, primocane fruiting cultivars (fruit produced on canes grown in the current and previous years) are grown. Old production fields are replanted with new crops in winter, which come into production approximately six months later. This results in an intensive 18-month production cycle with fruit harvested in two to three cycles before replanting. In contrast, Washington relies on floricane fruiting varieties (fruit produced exclusively on canes that grew in the previous year) that have a single production cycle per year for five to eight years. Plants in Washington are established in spring and come into production the following year. In both regions, raspberries are rarely rotated with other crops due to a lack of suitable ground for raspberry production as well as the high profit margin compared with other crops.

When raspberry follows raspberry, the soil is usually fumigated before planting to control two economically important soilborne pathogens: the fungal-like water mold Phytophthora rubi (W.F. Wilcox \& J.M. Duncan) Man in 't Veld (2007) and the plantparasitic nematode Pratylenchus penetrans (Cobb 1917) Filipjev and Schuurmans Stekhoven, 1941. Phytophthora rubi causes root rot and has been a commonly reported disease of red raspberry

Corresponding author: Inga Zasada; E-mail: inga.zasada@ars.usda.gov

This article is in the public domain and not copyrightable. It may be freely reprinted with customary crediting of the source. The American Phytopathological Society, 2017

since the early 1950s in western North America (Duncan et al. 1987; Wilcox 1989). Raspberries infected by P. rubi exhibit chlorotic leaves, wilting primocanes and floricanes, and poor fruit set. If formed, berries remain small and often wither before ripening. Over time, infected plants progressively decline, wilt, and die. Pratylenchus penetrans, a root lesion nematode, is also a major pest of red raspberry, reducing yield and cane growth (Zasada et al. 2015). This nematode is prevalent in Washington raspberry fields (Gigot et al. 2013a), but is not widespread in California raspberry fields. Pratylenchus penetrans invades fine roots where it feeds on cortical tissues, thereby directly reducing water and nutrient uptake, and consequently, yield of impacted plants.

Current management of soilborne pathogens and nematodes in raspberry revolves around preplant soil fumigation with 1,3dichloropropene (1,3-D) in Washington or methyl bromide in California, combined with chloropicrin. In a fumigant mix containing 1,3-D and chloropicrin (i.e., Telone C-35, Pic-Clor 60, or Tri-Form 80), 1,3-D is considered the nematicide while chloropicrin is considered the fungicide. In Washington, $95 \%$ of replanted fields and $50 \%$ of new fields are fumigated prior to raspberry establishment (Caneberry Workshop 2003). In California, $80 \%$ of production is conventional, with approximately 400 ha being preplant-fumigated annually (M. Bolda, personal communication). Recent changes in fumigant regulations and registrations are making preplant fumigation for raspberry growers more difficult. In 2009, US EPA Reregistration Eligibility Decision (RED) for chloropicrin made fumigation more difficult for most growers (by including buffer zones and fumigant management plans) (Anonymous 2009). In California, there are additional restrictions on soil fumigation including township caps, which place a geographic cap on 1,3-D use and upper limits on 
chloropicrin dose in sensitive sites (Verder-Carlos 2014). Additional restrictions on soil fumigation are expected for several fumigants (including 1,3-D) currently undergoing reregistration (https://www.epa.gov/soil-fumigants/regulatory-status-fumigants). It is also important to note that 2015 was the first year that methyl bromide was no longer available to raspberry growers in California because critical used exemptions (CUE) were not requested. The goal of this research was to identify modifications to current fumigation practices in raspberry to reduce buffer zones, improve efficacy of existing fumigants, and identify a viable fumigant alternative to methyl bromide suitable for the production of raspberry in the western United States.

\section{Comparing Efficacy of Tarped Bed Fumigation to Conventional Open Field Fumigation in Washington}

Three trials were established in northern Washington grower fields that had been in raspberry production for $>5$ years, to compare broadcast fumigation with bed fumigation. Prior to establishing each trial, canes of old raspberry plants were mowed in August/September 2010, the fields were ripped in multiple directions incorporating old plant material, and then the soil was prepared for soil fumigation as is standard practice between successive plantings. In all of the trials, the fumigant used for the fumigation treatments was 65:35 1,3-dichloropropene:chloropicrin (Telone C-35; Dow Agrosciences, Indianapolis, IN) at a rate of 433 $\mathrm{kg} / \mathrm{ha}$. The plots were established and fumigant treatments applied in September/October 2010.

The first trial (WA1) was established in Burlington, WA, on a very fine sandy loam soil. The following treatments were compared in a randomized complete block design with four replications: (i) broadcast fumigation nontarped; (ii) bed fumigation tarped; and (iii) nontreated. The treatments were applied to plots $9 \mathrm{~m}$ wide by $18 \mathrm{~m}$ long. The broadcast fumigation was applied using a commercial deep-shank application apparatus with shanks spaced $30 \mathrm{~cm}$ apart and with product applied $40 \mathrm{~cm}$ below the soil surface (Trident Agricultural Products, Woodland, WA). For this treatment, beds were formed the following spring prior to planting. For bed fumigation, beds ( $0.9 \mathrm{~m}$ wide by $0.2 \mathrm{~m}$ high) were formed with a Rain-Flo model 2600 bed shaper (Rain-Flo Irrigation, East Earl, PA) with the fumigant being injected into the beds by two shanks $30 \mathrm{~cm}$ apart at a depth of $30 \mathrm{~cm}$ from the top of the bed. These plots were then covered with black, virtually impermeable film (VIF; Blockade XL, Pliant Plastics, Spring Lake, MI) immediately after bed formation and fumigation
(Fig. 1). The nontreated plots were prepared similarly to the bedfumigated plots; however, no fumigant and no tarp were applied. The following spring, the tarp was removed from beds, and the field was planted to raspberry 'Meeker' as dormant canes on $0.8 \mathrm{~m}$ within row by $3.0 \mathrm{~m}$ between row spacing and managed for the duration of the trials by the growers following established recommendations (Anonymous 2005).

The other two Washington trials were established in Lynden, WA. Washington trial 2 (WA2) was conducted in a field with a sandy loam soil while the third trial (WA3) was conducted in a field with a silt loam soil. The following treatments were evaluated at WA2 and WA3 in a randomized block design with four replications: (i) broadcast fumigation nontarped; and (ii) bed fumigation tarped. The application of fumigants, broadcast and bed, was identical to that described for WA1. However, the size of the area to which treatments were applied were $6 \mathrm{~m}$ wide by $174 \mathrm{~m}$ long at WA2, and $9 \mathrm{~m}$ wide by $22 \mathrm{~m}$ long at WA3.

\section{Testing Efficacy of Pic-Clor 60 Relative to Methyl Bromide in California}

Trials were established in October 2010 (CA1) and September 2012 (CA2) in the same field location in Wastsonville, CA. Both trials were arranged in a randomized block design with three replications in 2010 and four replications in 2012. Treatments included: (i) nontreated, nontarped control; (ii) 57:43 methyl bromide:chloropicrin at a rate of $392 \mathrm{~kg} / \mathrm{ha}$; and (iii) 40:60 1,3-D: chloropicrin (Pic-Clor 60; DowAgroSciences) at a rate of $336 \mathrm{~kg} / \mathrm{ha}$ in 2010 and at a rate of $448 \mathrm{~kg} / \mathrm{ha}$ in 2012; the methyl bromide: chloropicrin treatment was tarped under standard film (1 mil; Trical, Hollister, CA) and the Pic-Clor 60 treatment was tarped under totally impermeable film (TIF 1.4 mil; Raven, Sioux Falls, SD) (Fig. 2). Fumigant treatments were applied to strips $23 \mathrm{~m}$ wide by $60 \mathrm{~m}$ long. The nontreated controls were placed randomly within these strips and were $23 \mathrm{~m}$ wide by $15 \mathrm{~m}$ long. Prior to planting the tarps were removed and then a proprietary raspberry cultivar (Plant Sciences, Inc., Watsonville, CA) as roots were distributed in furrows on 2-m spacing into the plots in October 2010 and December 2012. These raspberry plantings were managed for the duration by the grower cooperator following industry recommendations (Bolda et al. 2012).

\section{Nematode and Pathogen Assessments}

To determine $P$. rubi and $P$. penetrans population dynamics in soil and roots, a sampling area $(10 \mathrm{~m}$ long by $1.2 \mathrm{~m}$ wide within

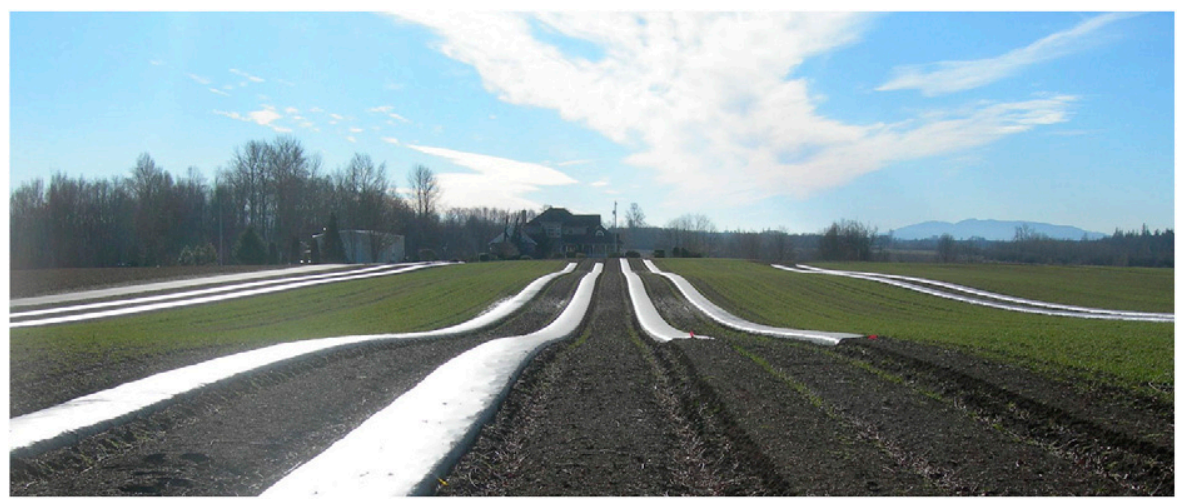

\section{FIGURE 1}

On-farm trials were established at three sites in northern Washington raspberry fields. Tarped bed fumigation with 1,3-dichloropropene:chloropicrin (Telone C-35) was compared with the industry standard of nontarped broadcast fumigation with Telone C-35. 


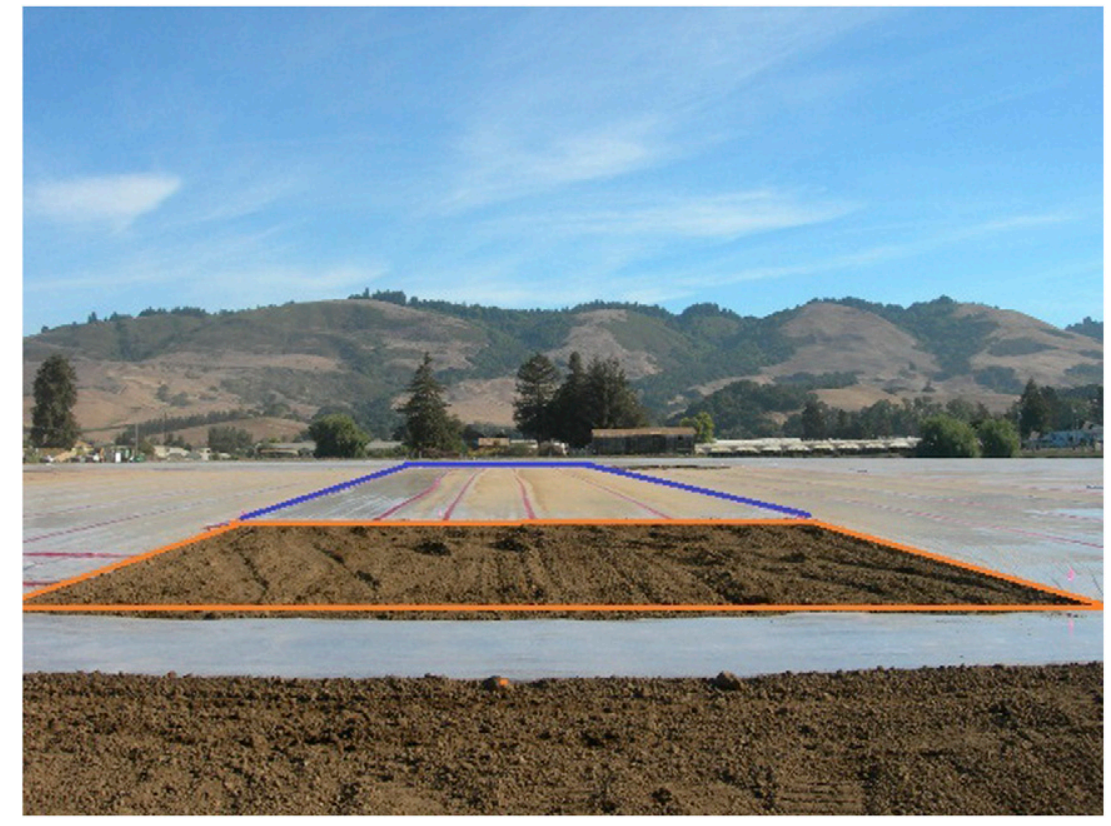

FIGURE 2

Trials in California raspberry included comparing the industry standard of methyl bromide:chloropicrin to 1,3-dichloropropene:chloropicrin (Pic-Clor 60) and a nontreated control. Fumigation treatments were tarped and applied to $23-\mathrm{m}$-wide by $60-\mathrm{m}$-long plots (outlined in blue) while the nontreated control was not tarped and applied to 23 -m-wide by 15 -m-long plots (outlined in orange).

a single row) was established within each of the larger fumigated/ nonfumigated plots in all trails in Washington and California. Samples were collected in the fall (September to October) and spring (April to May) of each year. From each sampling area (here within referred to as plot), eight soil cores $(2.5 \mathrm{~cm}$ in diameter and $25 \mathrm{~cm}$ deep) were collected at equal distances along the plot within $15 \mathrm{~cm}$ of the crown of the plant, combined, and placed in a plastic bag. In addition, two $15 \times 15-\mathrm{cm}$ root cores to a depth of $25 \mathrm{~cm}$ were collected within a $20-\mathrm{cm}$ radius of two different plant crowns within the plot using a square-blade shovel; roots were separated from the soil with excess soil being discarded and then roots were placed in the bag containing the composite soil sample. In Washington, soil samples were also collected from within the alleys between the raspberry rows and assessed for both $P$. penetrans and $P$. rubi as described below.

Mixed life stages of $P$. penetrans were extracted from a 50-g subsample of soil using the Baermann funnel method and nematodes were collected after 5 days (Ayoub 1980). From the root samples, $P$. penetrans were extracted from fine roots $(\leq 2 \mathrm{~mm}$ in diameter) under intermittent mist for 1 week (Ayoub 1980). Extracted roots were then placed in a $70^{\circ} \mathrm{C}$ oven for 1 week before measuring dry weights. Nematodes were counted using a stereomicroscope at $\times 40$ magnification and expressed as number of $P$. penetrans $/ 100 \mathrm{~g}$ soil or $P$. penetrans/g dry root. Nematodes were identified as $P$. penetrans based upon morophological features and the presence of males (Castillo and Vovlas 2007).

Phytophthora rubi was baited from the same soil samples that were used for nematode quantification using a Cone-tainer (245 mm; D4OH Deepots; Stuewe and Sons, Inc., Tangent, OR) bioassay. Cone-tainers were filled with $50-\mathrm{ml}$ sanitized gravel, followed by $50-\mathrm{ml}$ soil-free potting mix, and then a $450 \mathrm{ml}$ of a collected soil sample. A raspberry 'Meeker' tissue culture plant (3 to 4 weeks old; Sakuma Bros., Burlington, WA) was placed directly on top of the soil sample. The remaining area of the Conetainer was filled with the corresponding soil sample to $2.5 \mathrm{~cm}$ from the top of the pot. Disease caused by $P$. rubi was encouraged by flooding the pots for $48 \mathrm{~h}$ every two weeks as described by Gigot et al. (2013a). Controls-field soil corresponding to each site autoclaved for $30 \mathrm{~min}$ at $121^{\circ} \mathrm{C}$, flooded and nonflooded-were included in the experimental design. All bioassays were arranged in a randomized block design with four replicate plants per soil sample. Plants were grown in a greenhouse maintained at $16^{\circ} \mathrm{C}$ with a $12 \mathrm{~h}$ day/night light cycle for 8 to 12 weeks, until differences in shoot growth were apparent. Plants were then gently separated from soil and were washed with tap water to remove excess soil. The proportion of symptomatic roots was evaluated on a modified 0 to 7 Horsfall-Barratt-type scale (Horsfall and Barratt 1945), with $0=0$ to $12.5 \%, 1=12.5$ to $25 \%$, $2=25$ to $37.5 \%, 3=37.5$ to $50 \%, 4=50$ to $62.5 \%, 5=62.5$ to $75 \%$, $6=75$ to $87.5 \%$, and $7=87.5$ to $100 \%$ of roots symptomatic. Shoots and roots were separated and dried at $72{ }^{\circ} \mathrm{C}$ for $72 \mathrm{~h}$ prior to determining dry weights.

\section{Plant Vigor and Yield Assessments}

Plant performance was evaluated over the course of the trials. In the Washington trials, the longest three canes per plant of each of three plants per plot were measured in October 2011. In July 2012 yield was assessed in the Washington trials. Fruit was harvested with growers' mechanical harvesters from the entire length of the treated areas (beyond the established sampling plots). Weight of fruit harvested in each treatment replicate was recorded once a week during the four-week-long harvest period. In the CA1 trial, fruit yield was evaluated from July to November 2011 (40 picks) and May to July 2012 (27 picks) by hand-harvesting the berries from both sides of the plot established for pathogen assessment. Once harvested, fruit were counted and weighed. In the CA2 trial, fruit yield was evaluated in the same manner from July to November 2013 (total of 51 picks) and then again from May to July 2014 (total of 23 picks). Plant heights of three randomly chosen canes from each plot were measured in August 2013 in CA2. 


\section{Statistical Analyses}

Pratylenchus penetrans data were $\log _{10}(\mathrm{x}+1)$ transformed when necessary to meet the assumptions of the statistical models. When multiple measurements were collected from a plot (plant bioassay and proportion of symptomatic roots from root rot assays and cane height) at any given time, the average of these measurements was calculated for each plot and used in the statistical analysis. All data except proportion of symptomatic root ratings from the root rot assay were analyzed by ANOVA, with fumigation treatments and nontreated controls (WA1, CA1, and CA2) as fixed effects and block as a random effect. Mean separation among treatments was performed using Fisher's protected least significant difference (LSD) at $P<0.05$. Proportion of symptomatic root ratings from root rot assays were examined for significant differences by the KruskalWallis test. Duncan's multiple range test was used to separate means at $P<0.05$. All statistical analyses were conducted using JMP 9.1 (SAS Institute Inc., Cary, NC).

\section{Bed Fumigation is as Effective as Broadcast Fumigation in Washington Raspberry Production}

Currently, an untarped broadcast fumigation with Telone C-35 is the industry standard in northern Washington raspberry production fields. There are many attributes of raspberry production and current fumigant application strategies that warrant consideration of alternatives. The majority of processed raspberries are grown in Whatcom Co., a region that is becoming more urbanized. Raspberry fields are often near houses or other occupied structures. Due to the US EPA RED (Anonymous 2009), the use of an untarped application of Telone C-35 within close proximity to urban areas has become much more difficult for many raspberry growers because buffer zones, a distance between the application site (i.e., edge of field) and bystanders, are required (Anonymous 2012). For example, even with a $20 \%$ buffer credit for 2 to $3 \%$ soil organic matter, an untarped broadcast application of Telone C-35 at a labeled rate of $365 \mathrm{~kg} / \mathrm{ha}$ to an 8-ha field results in a $115-\mathrm{m}$ buffer surrounding the treated area for $48 \mathrm{~h}$ after fumigation (2012, Telone C-35 Specimen Label, Dow AgroSciences). Transitioning to a bed application of Telone C-35 at the same rate with or without the use of a tarp would reduce this buffer size to $7 \mathrm{~m}$.

Each of the sites included in this study had unique attributes, including different pathogen and nematode pressures and soil types. However, the data across our trials demonstrates that tarped bed fumigation is a viable alternative to broadcast fumigation in this production system. The diversity of sites included in this study provides additional confidence that this is a fumigation practice that has the potential for widespread implementation by the Washington raspberry industry.

Site WA1 was considered to be at high risk from $P$. rubi and $P$. penetrans because of root rot symptoms observed in the previous planting and high $P$. penetrans population densities compared with other surveyed fields in the region (Gigot et al. 2013a). This was also the only trial in which a nontreated control was included. Tarped bed and nontarped broadcast fumigation initially reduced $P$. penetrans population densities in soil at planting (spring 2011) to low levels ( $<7$ nematodes/100 g soil) compared with the nontreated control $(P=0.02$; Fig. $3 \mathrm{~A})$. Six months after planting (fall 2011), this difference was still evident for soil population densities $(P=0.01)$, but this same trend was not observed with root population densities (Fig. 3B). One year after planting (spring 2012), and afterward, no further differences in $P$. penetrans population densities in soil were observed among the treatments. Treatment differences were observed in $P$. penetrans population densities in roots one (spring 2012) and 1.5 (fall 2012) years after planting $(P<0.01)$, with few nematodes being isolated from the roots of plants grown in tarped bed-fumigated plots compared with nontreated and nontarped broadcast-fumigated plots (Fig. 3B).

At WA1, the first treatment effects on $P . r u b i$ were detected six months after planting (fall 2011). Plants grown in soil collected from tarped bed-fumigated plots had greater root biomass $(1.1 \mathrm{~g}$ ) compared with plants grown in soil collected from nonfumigated ( $0.4 \mathrm{~g}$ root biomass) and broadcast-fumigated ( $0.7 \mathrm{~g}$ root biomass) plots $(P=0.05)$. At 2.5 years after planting (fall 2013), shoot mass was significantly greater for the raspberry plants grown in soil collected from tarped bed-fumigated areas $(5.9 \mathrm{~g})$ compared with that from nontarped broadcast-fumigated areas $(2.5 \mathrm{~g})(P=0.02)$. This was a high-disease-pressure field and by fall 2012, many of the plants in this field were severely impacted by Phytophthora root rot. The severe disease pressure in this field might also explain the decline in $P$. penetrans population densities in roots after 2 years (spring 2013; Fig. 3B). Fine roots are the preferred feeding site for $P$. penetrans (Castillo and Vovlas 2007); a reduction in fine root abundance due to $P$. rubi may have eliminated the food source for the nematode.

WA1 was the only site in which a difference in vigor (cane height) and yield of raspberry among the treatments was observed (Table 1). Three months after planting, canes of plants grown in tarped bed-fumigated areas were longer than canes of plants grown in nontarped broadcast-fumigated or nontreated areas. This difference in plant productivity continued to be observed over a year after planting with a 47 to $70 \%$ increase in yield of raspberry plants grown in tarped bed-fumigated areas compared with plants grown in nontarped broadcast-fumigated and nontreated areas, respectively. At this site, it appears that protection from $P$. penetrans or other soilborne pathogens during crop establishment by using a tarped bed-fumigation application increased the raspberry yield.

The other two sites, WA2 and WA3, were considered to have moderate $P$. penetrans pressure (Gigot et al. 2013a). At both of these sites, the same trend was observed with low ( $<8$ nematodes/ $100 \mathrm{~g}$ soil) $P$. penetrans population densities in soil in both tarpedbed and untarped broadcast-fumigated plots until one year after planting (spring 2012; Fig. 3C and 3E). During the next year (fall 2012 and spring 2013), P penetrans population densities in soil were lower in tarped bed-fumigated areas compared with nontarped broadcast-fumigated areas $(P<0.05)$. The response of $P$. penetrans population densities in roots varied between the two moderate pressure sites. At WA2, there was an early suppression of $P$. penetrans population densities in roots of plants grown in tarped bed-fumigated areas compared with nontarped broadcast-fumigated areas during the first three sampling dates (Fig. 3D). At WA3, there were similar densities of $P$. penetrans in roots among the fumigation treatments up to 1.5 years after planting (fall 2012) (Fig. 3F). However, at the last two sampling dates (spring and fall 2013), $P$. penetrans population densities in roots were lower in tarped bedfumigated areas compared with nontarped broadcast-fumigated areas $(P<0.05)$. Based upon the previous raspberry crop, WA2 was at low risk, while WA3 was at high risk from Phytophthora root rot. A difference between the fumigation treatments in suppression of $P$. rubi was only observed at WA3 at planting in spring 2011, with a lower proportion of symptomatic bioassay roots grown in tarped bed-fumigated soil (2.3) compared with nontarped broadcast-fumigated soil $(5.3 ; P=0.05)$. At both of these sites, plants grown in tarped bed-fumigated plots were as productive as corresponding plants grown in nontarped broadcast-fumigated plots (Table 1). 

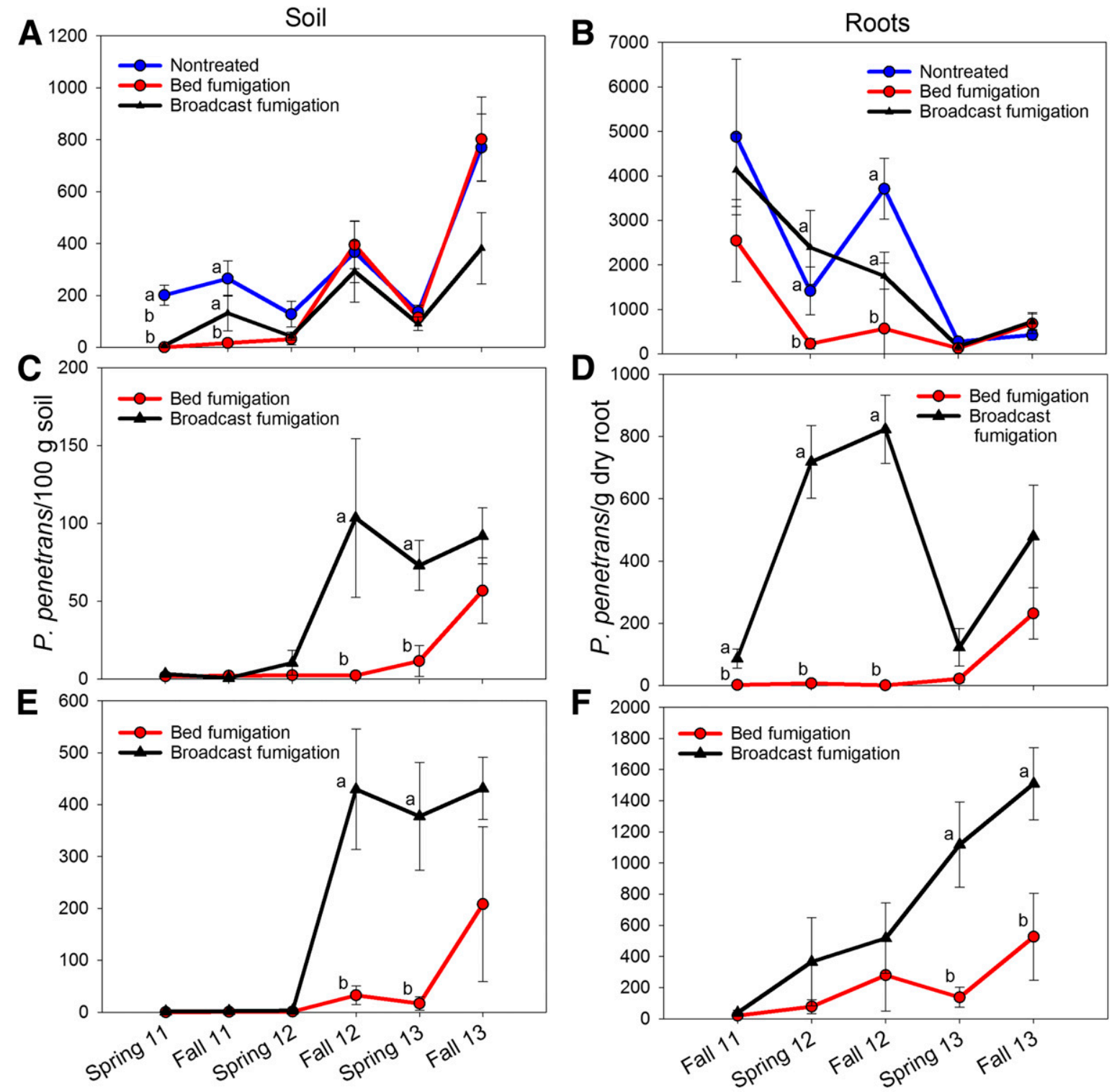

Sampling date

\section{FIGURE 3}

Population dynamics of Pratylenchus penetrans of raspberry in soil $(\mathbf{A}, \mathbf{C}, \mathbf{E})$ and roots $(\mathbf{B}, \mathbf{D}, \mathbf{F})$ in three field trials in Washington state evaluating fumigation alternatives. Data from each trial is presented separately, as WA1 (A and B), WA2 (C and D), and WA3 (E and F). Within a trial and sample type, data points with the same letter are not significantly different according to Fisher's protected least significant difference $(P<0.05)$. Nontransformed data are presented; however, data were $\log _{10}(x+1)$ transformed prior to analysis when necessary to meet the assumptions of the statistical model.

At all of the sites, soil was also collected from between the rows to determine if this area could potentially serve as a source of $P$. penetrans and $P$. rubi inoculum to raspberry plants within the rows. At the high $P$. penetrans pressure site WA1, P. penetrans was found in the alleys at densities ranging from 3 to $174 P$. penetrans $/ 100 \mathrm{~g}$ soil. Differences among the treatments were not observed until spring 2013 when densities were lower (25 P. penetrans/100 g soil) in nontarped broadcast-fumigated areas compared with tarped bedfumigated and nontreated areas (66 and 79 P. penetrans $/ 100 \mathrm{~g}$ soil, respectively) $(P=0.01)$. This trend was observed again in fall 2013 $(P=0.04)$. At the other two Washington sites, few nematodes were recovered from the alleyways regardless of treatment, with maximum densities of $6 P$. penetrans $/ 100 \mathrm{~g}$ soil. More differences were observed in the $P$. rubi bioassay where soil samples from the alleyways were evaluated. At WA1, differences in the bioassay root disease severity ratings in soil collected in spring 2012 and 2013 were observed (data not shown). In spring 2012, the bioassay root disease severity ratings from tarped bed-fumigated areas were higher, 6.0, than those from nontarped broadcast-fumigated areas, $4.0(P<0.03)$. The following spring, 2013, the root disease severity of plants grown in soil from tarped bed-fumigated areas was higher, 5.8, than those from nontarped broadcast-fumigated areas, $3.3(P=$ 0.01). This same trend was observed at WA3 in spring 2011, six months after fumigation. At this time, plants grown in soil from tarped bed-fumigated areas had higher disease severity root ratings, 6.7, than those from nontarped broadcast-fumigated areas, $4.0(P=$ 0.02). Differences were also observed in root and shoot biomass of bioassay plants, with greater root biomass of plants grown in 


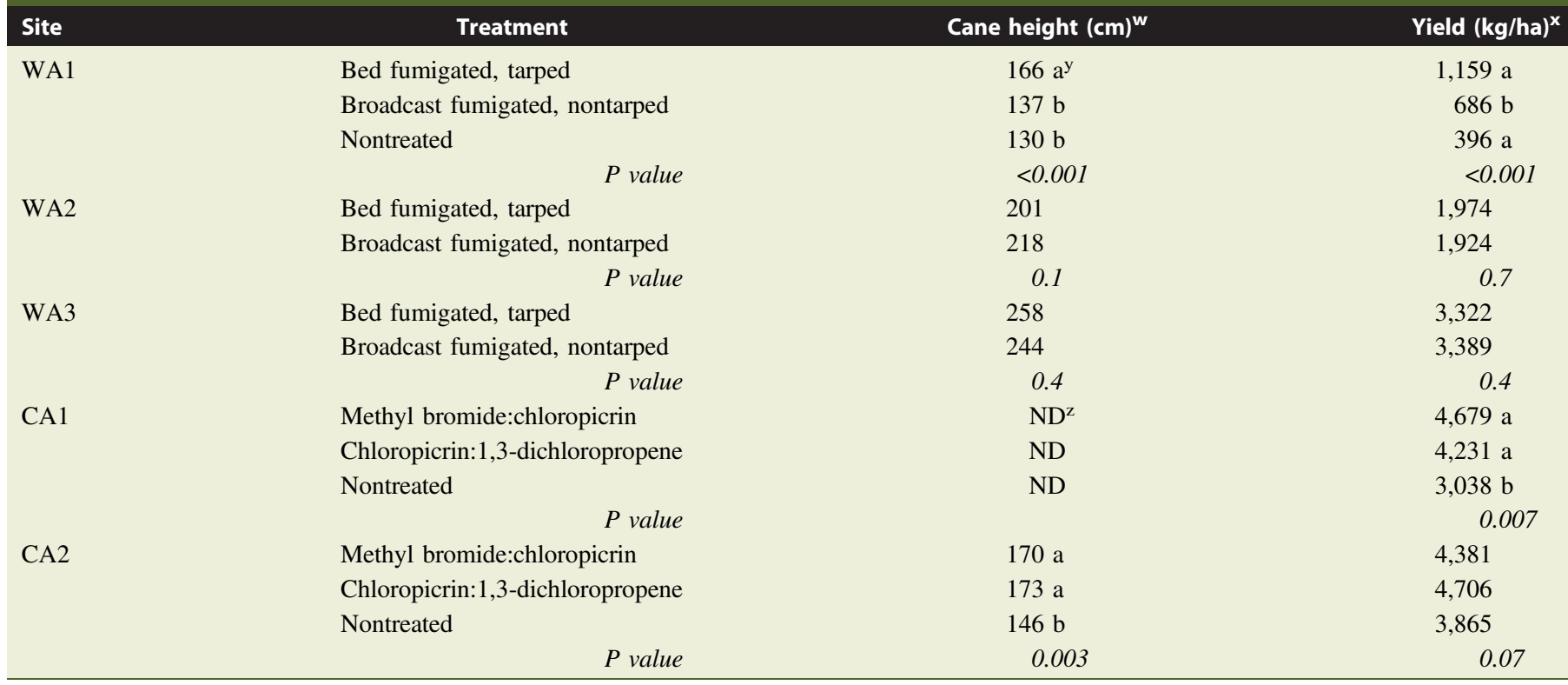

${ }^{\mathrm{v}} \mathrm{WA}=$ Washington. The trials in Washington were established in September/October 2010. Fumigated plots were treated with 65:35 1,3-dichloropropene (1,3-D):chloropicrin (Telone C-35; Dow Agrosciences) at a rate of $433 \mathrm{~kg} / \mathrm{ha} . \mathrm{CA}=$ California. CA1 was established in September/October 2010 and CA2 was established in September/October 2012. Methyl bromide:chloropicrin fumigation was at a rate of $392 \mathrm{~kg} / \mathrm{ha}$ while 40:60 1,3-D:chloropicrin (PicChlor 60; DowAgroSciences) was applied at a rate of $336 \mathrm{~kg} / \mathrm{ha}$ in CA1 and at a rate of $448 \mathrm{~kg} / \mathrm{ha}$ in CA2; all fumigant treatments were tarped.

${ }^{\mathrm{w}}$ Cane heights (the longest three canes of three plants in a 10-m-long area) were determined in July 2011 in Washington and August 2013.

${ }^{\mathrm{x}}$ In Washington, yield was determined by collecting berries three to four times during the harvest season during July and August 2012. Yield in California was determined by hand harvesting the berries three to four times weekly for the duration of harvest (July to November in the fall, and May to July in the spring).

${ }^{y}$ Values are the means of three or four replications. Means within a site followed by the same letter are not significantly different according to Fisher's protected least significant difference test $(P<0.05)$.

${ }^{\mathrm{z}} \mathrm{ND}=$ not determined.

nontarped broadcast-fumigated soil $(0.95 \mathrm{~g})$ than from plants grown in nontreated and tarped bed-fumigated soil $(0.45$ to $0.58 \mathrm{~g}$, respectively) at WA1 in spring $2013(P=0.03)$. Plant growth differences were also observed at WA3 in fall 2012 with greater shoot biomass of plants grown in nontarped broadcast-fumigated soil $(8.1 \mathrm{~g})$ compared with tarped bed-fumigated soil $(4.8 \mathrm{~g})(P<0.04)$.

Combined, these results indicate that the risk of leaving alleyways untreated may be greater for $P$. rubi than for $P$. penetrans. This is especially true when the life cycle of $P$. rubi is considered (Erwin and Ribeiro 1996). As water molds, Phytophthora spp. thrive in wet conditions with the formation of zoospores under saturated conditions which can readily move in water. Phytophthora rubi (=P. megasperma) was highly pathogenic to raspberry under wet and dry conditions; however, disease severity increased for one isolate after longer periods of waterlogging (Duncan and Kennedy 1989). While the movement of $P$. rubi zoospores has not been evaluated, other Phytophthora species have been shown to move efficiently in soil, including $P$. cryptogea which moved $40 \mathrm{~mm}$ in a coarse soil column (Duniway 1976). In northern Washington, where an average of $116 \mathrm{~cm}$ of rain falls annually, there is the potential for the movement of $P$. rubi zoospores from the alleyways into the raspberry beds when soils become saturated or in low-lying areas.

Our results in Washington demonstrate that raspberry growers should consider the use of a tarped bed fumigation. However, the advantages and disadvantages of transitioning to this practice must be considered. Another advantage, above and beyond soilborne pathogen and nematode suppression and equivalent plant growth to that achieved by broadcast fumigation, is the potential for earlier planting in the spring. If the tarp is left on the beds over the winter there may be an opportunity for growers to plant earlier due to warmer soil temperatures and also because beds are already formed. As stated above, this region receives abundant rain during the winter (typically 65 to $75 \mathrm{~cm}$ between October and March), and often growers need to wait until soils dry to be able to form beds; in a bed-fumigated field, beds would already be formed in the spring.

\section{Pic-Clor60 Can Be As Effective As Methyl Bromide in California Raspberry Production}

The fumigation situation in California raspberry differs from that in Washington. First, this industry has been able to use methyl bromide until just recently (2015), so grower familiarity and experience with products other than methyl bromide such as 1,3-D are limited. Second, because of more stringent fumigation regulations in California (Verder-Carlos 2014), the use of TIF is already a common practice for these growers. The primary soilborne pathogen target is P. rubi (Bolda et al. 2012). Plant-parasitic nematodes are rarely of concern in the California raspberry production system because of the frequent (every 18 months) use of preplant fumigation to reestablish plantings.

The field in which these trials were conducted did not have a high incidence of root rot; therefore, no difference was observed between treatments in root rot incidence as measured by the soil bioassay (data not shown). Despite low disease pressure, an increase in production was still observed in plants grown in fumigated soil compared with nonfumigated soil (Table 1). This was reflected initially at CA2 with canes of plants grown in Pic-Clor60 and methyl bromide-fumigated 
areas being 14 to $15 \%$ longer than canes of plants grown in nontreated plots. A difference in yield was observed at CA1 with 35 and $28 \%$ more fruit in areas treated with methyl bromide:chloropicrin and Pic-Clor60, respectively, compared with yield in the nontreated areas. A similar nonsignificant $(P=0.07)$ trend in yield was observed in CA2. PicClor60 has been demonstrated to be as effective a methyl bromide in other high-value crop production systems. As of $2011,68 \%$ of the California strawberry acreage was fumigated with combinations of 1,3-D and chloropicrin (Fennimore et al. 2013). Indeed, this combination has become the most commonly used fumigant in caneberries and strawberries with the phase out of the use of methyl bromide.

\section{Conclusions and Management Considerations}

Red raspberry production in the western United States encompasses two very different types of systems; therefore, one fumigation system will not meet the needs of both industries. Practical conclusions from this research include the following.

Fumigant choice. In California, soilborne fungal-like pathogens are the target; therefore, fumigants with a larger percentage of chloropicrin (Pic-Clor60 and TriForm80) are preferred. Every field is different, but our research demonstrates that Pic-Clor60 can be as effective as methyl bromide:chloropicrin in maintaining raspberry productivity in California. This is in contrast to Washington, where plant-parasitic nematodes are also of concern and the most common fumigant used is Telone C-35.

Bed versus broadcast fumigation. Our research demonstrates that tarped bed fumigation with Telone C-35 is a viable alternative to broadcast fumigation using the same fumigant without a tarp, the industry standard in Washington. Leaving the alleyways untreated did not appear to pose a risk to plants in the row from $P$. penetrans. In the Washington raspberry production system, the alleyways are kept bare throughout the lifetime of the planting ( 5 to 8 years). From a $P$. penetrans management perspective, the lack of a host in the alleyways (essentially fallow) means that nematodes surviving in the alleys would not have a host and population densities over time will decline (Kroese et al. 2016). However, the risk of residual $P$. rubi surviving in the alleyways in a bed-fumigation scenario may be more problematic. In fact, this has become the case in California, where strawberry fields receiving bed fumigation with alternatives to methyl bromide resulted in the emergence of a novel plant collapse problem (Koike et al. 2013). With the shorter, 18-month rotations used in California raspberry, there appears to be insufficient time to exhaust soilborne pathogen levels left untreated in the alleyways.

Tarps. An additional consideration for both Washington and California is that tarps cannot be left on the field at planting because emerging canes from planted roots cannot penetrate the plastic. In California, bed fumigation is not currently considered economical because of the cost of removing the plastic after fumigation; the same would be true in Washington.

Constraints to adoption. In Washington, the first constraint to adoption is cost, with the addition of a VIF or TIF tarp to a bed application adding an additional approximately \$200/ha. What might ultimately drive the widespread use of tarps during fumigation may be the inability to apply 1,3-D:chloropicrin as a broadcast fumigation because of buffer-zone concerns. Resistance by growers also revolves around bed shaping. Each raspberry grower has a different idea regarding the shape and size of beds. In addition, efficient use of other equipment in the fields relies upon accurate bed establishment. Currently, there is only one bed-fumigation rig available in Washington; it may or may not pull beds that are acceptable (right size, right tilth, right position) for a grower. In California, there are few constraints to the adoption of 1,3-D:chloropicrin fumigation in combination with TIF tarps since few other proven alternatives are available.

Alternatives to soil fumigation. Nonfumigant alternatives as well as other fumigants for soilborne pathogen and plant-parasitic nematode suppression in California and Washington raspberry still need to be identified. Alternatives that have received consideration in other high value crop production systems include brassica-seed meals (Gigot et al. 2013b), anaerobic soil disinfestation (Shennan et al. 2015), and other fumigants such as metam sodium and dimethyl disulfide (Cabrera et al. 2014; López-Aranda et al. 2016).

\section{Acknowledgments}

We thank Jack Pinkerton, Duncan Kroese, and Don Wallace for technical assistance. This research was partially funded by the United States Department of Agriculture NIFA-RAMP grant 2010-5110121649 .

\section{Literature Cited}

Anonymous. 2005. Berry Production Guide. Lower Mainland Horticulture Improvement Association, Vancouver, British Columbia.

Anonymous 2009. Amended reregistration eligibility decision (RED) for chloropicrin. Prevention, Presticides and Toxic Submstances Publ. 7508P. United States EPA. Washington, DC.

Anonymous 2012. Soil fumigant mitigation factsheet: Buffer zones. Office of Pesticides Programs Publ. 7506P. United States EPA. Washington, DC.

Ayoub, S. M. 1980. Plant Nematology, An Agricultural Training Aid. NemaAid Publ., Sacramento, CA.

Bolda, M., Gaskell, M., Mitcham, E., and Cahn, M. 2012. Fresh Market Caneberry Production Manual. Agr. and Natural Resources. Publ. 3525. Univ. of Calif., Davis.

Cabrera, J. A., Wang, D., Gerik, J. S., and Gan, J. 2014. Spot drip application of dimethyl disulfide as a post-plant treatment for the control of plant parasitic nematodes and soilborne pathogens in grape production. Pest Manag. Sci. 70: 1151-1157.

Castillo, P., and Vovlas, N. 2007. Pratylenchus (Nematoda: Pratylenchidae): Diagnosis, Biology, Pathogenicity and Management. Brill, Leiden, The Netherlands.

Caneberry Workshop. 2003. Pest Management Strategic Plan: Caneberry Production in Washington and Oregon. Attendee report for PNW Caneberry Industry, USDA and EPA. Regional IPM Centers. http://www.ipmcenters. org/pmsp/pdf/PNWCaneberryPMSP.pdf.

Duncan, J. M., and Kennedy, D. M. 1989. The effect of waterlogging on Phytophthora root rot of red raspberry. Plant Pathol. 38:161-168.

Duncan, J. M., Kennedy, D. M., and Seemuller, E. 1987. Identities and pathogenicities of Phytophthora spp. causing root rot of red raspberry. Plant Pathol. 13:352-357.

Duniway, J. M. 1976. Movement of zoospores of Phytophthora crytogea in soils of various textures and matric potentials. Phytopathology 66: 877-882.

Erwin, D. C., and Ribeiro, O. K. 1996. Phytophthora Diseases Worldwide. American Phytopathological Society, St. Paul, MN.

Fennimore, S. A., Serohijos, R., Samtani, J. B., Ajwa, H. A., Subbarao, K. V., Martin, F. N., Daugovish, O., Legard, D., Browne, G. T., Muramoto, J., and Shennan, C. 2013. Methods to facilitate the adoption of alternatives to methyl bromide soil fumigation by California strawberry growers. Calif. Agric. 67: $139-146$

Gigot, J., Walters, T. W., and Zasada, I. A. 2013a. Impact and occurrence of Phytophthora rubi and Pratylenchus penetrans in commercial red raspberry (Rubus idaeus) field in northwestern Washington. Int. J. Fruit Sci. 13: 357-372.

Gigot, J. A., Zasada, I. A., and Walters, T. W. 2013b. Integration of brassicaceous seed meal into red raspberry production systems. Appl. Soil Ecol. 64:23-31.

Horsfall, J. G., and Barratt, R. W. 1945. An improved grading system for measuring plant disease. Phytopathology 35:655.

Koike, S. T., Gordon, T. R., Daugovish, O., Ajwa, H., Bolda, M., and Subbarao, K. 2013. Recent developments on strawberry plant collapse problems in California caused by Fusarium and Macrophomina. Int. J. Fruit Sci. 13: 76-83. 
Kroese, D. R., Weiland, J. E., and Zasada, I. A. 2016. Distribution and longevity of Pratylenchus penetrans in the red raspberry production system. J. Nematol. 48: 241-247.

López-Aranda, J. M., Gómez, F., Puga, M., Zamora, R., Daugovish, O., and Cotero, M. A. 2016. Chemical soil fumigation for raspberry nursery in Jalisco (Mexico). J. Berry Res. 6:37-46.

Shennan, C., Muramoto, J., Baird, G., Zavatta, M., Toyama, L., Mazzola, M., and Koike, S. T. 2015. Anaerobic soil disinfestation (ASD): A strategy for control of soil borne diseases in strawberry production. Int. Sym. on Innovation and Integrated and Organic Hort. 1137:113-120
Verder-Carlos, M. N. 2014. Memorandum: Recommendation on township cap exception requests for 1,3-dichlorpropene. Depart. of Pesticide Regulation, Calif. Enviromental Prot. Agency, Sacramento, CA. http://www.cdpr.ca.gov/ docs/emon/methbrom/telone/rec_on_twnshp_telone.pdf

Wilcox, W. F. 1989. Virulence and isolation frequency of seven Phytophthora spp. causing root rot of raspberry in New York. Phytopathology 79:93101.

Zasada, I. A., Weiland, J. W., Han, Z., Walters, T. W., and Moore, P. 2015. Impact of Pratylenchus penetrans on establishment of red raspberry. Plant Dis. 99:939-946. 